\title{
ESTIMATES OF COMBINING ABILITY FOR SOME AGRO-MORPHOLOGICAL TRAITS ON SOME RICE GENOTYPES. \\ Sultan,M.S. ;M.A.Abdel-Moneam*;S.A.Hammoud ${ }^{\star *}$ and \\ A. G. Hefena ** \\ *Agronomy Department, Fac. of Agric., Mansoura Univ., Mansoura, Egypt. \\ ${ }^{\star *}$ Rice Research Section, Field Crops Research Institute, ARC, Giza, Egypt.
}

\begin{abstract}
Field experiment was carried out at the Experimental Farm of Rice Research and Training Center,(RRTC), Sakha, Kafr EL-Sheikh, Egypt during 2010 and 2011 summer seasons. In order to estimate general combining ability (GCA) and specific combining ability (SCA) effects of the parents and their $F_{1}$ for some agronomic and yield and its component traits. This study involving ten rice genotypes, i.e. three commercial varieties (Giza178, Sakha103 and Sakha106), one promising line Gz 9057-6-1-3-2 (Giza179) and six Egypt/America bold grains genotypes (SKC 23819189-1-1-1-3-1-2-4-2, SKC 23819-192-2-1-2-2-4-2-1-2, SKC 23819-192-2-1-2-3-1-1-12, SKC 23819-192-2-1-2-4-5-3-2-1, SKC 23819-192-2-2-1-1-2-1-2-2 and SKC 23819192-2-2-1-1-2-2-1-2. The parental genotypes have a wide range of variations for all studied traits, origin, pedigree and group type. Ten parental genotypes in this study were sown in three sowing dates. A line $x$ tester cross was conducted among the ten parents (four lines and six testers) in (2010) to produce (24) crosses. The parental genotypes and their 24 crosses were studied for eight traits i.e. No of days to heading (day), plant height $(\mathrm{cm})$, number of tillers plant ${ }^{-1}$, flag leaf area $\left(\mathrm{cm}^{2}\right)$, grain yield plant (g), number of panicles plant ${ }^{-1}, 1000$-grain weight $(\mathrm{g})$, and number of filled grains panicle $^{-1}$ the mean square of parents, crosses and parents vs. crosses revealed highly significant variations for all traits under investigation. GCA were found to be highly significant for all studied traits, except grain yield plant $^{-1}$ and 1000 -grain weight for Sakha 103 and grain yield plant ${ }^{-1}$ for line (Gz 9057-6-1-3-2) which was found to be not significant while testers, namely SKC 23819-189-1-1-1-3-1-2-4-2, SKC 23819-192-21-2-3-1-1-1-2 and SKC 23819-192-2-2-1-1-2-1-2-2 were also not significant for grain yield plant ${ }^{-1}$. Sakha 103 and Sakha 106 were good combiners for early maturing. Regarding to number of tillers plant ${ }^{-1}$, flag leaf area $\left(\mathrm{cm}^{2}\right)$, number of panicle plant ${ }^{-1}$ and number of filled grains panicle ${ }^{-1}$, the parental variety, Gz 9057-6-1-3-2 exhibited highly significant positive GCA effects for these traits. The rice variety Sakha 106 was found to be highly significant positive GCA effects for 1000-grain weight and grain yield plant ${ }^{-1}$. While, SKC 23819-192-2-2-1-1-2-1-2-2 proved to be excellent combiner for 1000-grain weight, while SKC 23819-192-2-2-1-1-2-2-1-2 was the best combiner also for the grain yield plant ${ }^{-1}$ this traits would be of practical interest in breeding program towards developing high yielding genotypes. Three out of the twenty four rice hybrid combinations showed highly significant positive SCA effects for grain yield plant $^{-1}$, 1000-grain weight and number of filled grains panicle ${ }^{-1}$, this combinations, were Sakha 103 x SKC 23819-192-2-1-2-2-4-2-1-2, Giza 178 x SKC 23819-189-1-11-3-1-2-4-2 and Giza 179 x SKC 23819-192-2-1-2-3-1-1-1-2.

Keywords: Rice, Combining ability, gene action, rice genotypes.
\end{abstract}




\section{INTRODUCTION}

Rice is one of the most important food crop in the world since it is the stable food for nearly $50 \%$ of the world population. Great advances have occurred in rice production as a result of the wide-scale adoption of improved rice varieties. However, demand for rice in low-income countries continues to increase because of increases in the population of rice consumers and improvements in living standards. It is estimated that the world will have to produce $50 \%$ more rice by 2050 . To meet this challenge, high yielding potential varieties are needed. Several approaches have been employed for developing rice varieties with high yielding potential, such as population improvement, ideotype breeding, heterosis breeding, wide hybridization, genetic engineering and molecular breeding (Khush, 1999). In self-pollinated crops like rice, the good of abrades is to develop true breeding homogeneous population with superior of agronomic and other desirable characteristics. Accomplishment of these objectives would depend on the suitable choice of the parental material, nature of gene action controlling characters under consideration and rational choice of breeding method for bringing about quick and maximum genetic improvement. This would imply that basic knowledge of the genetic behavior of the characters under improvement is a pre-request for breeder to manipulate the breeding material in order to isolate superior lines. The line by testers analysis have been used in recent years by many breeders and genetics to evaluate parental materials before taking any decisions concerning the type of breeding system to be used in this concern. So, combining ability analysis is the most widely used biometrical tool for classifying lines in terms of their ability to combine in hybrid combinations. With this method the resulting total genetic variation is partitioned into general combining ability, measure of additive gene action and specific combining ability measure of non-additive gene action, Hammoud (2004), Kumar et al. (2010), EL-Rawainy et al. (2011), Asfaliza et al. (2012), EL-Namaky (2012) and Kelah (2012). This investigation aimed to analyze GCA and SCA of the parents and their $F_{1}$ for some agronomic and physiological traits to identification of the best parents which the breeder can used in hybrid program.

\section{MATERIALS AND METHODS}

The research work of the present study was carried out at the Experimental Farm of the Rice Research and Training Center (RRTC), Sakha, Kafr EL-Sheikh, Egypt, during 2010 and 2011 successive rice seasons. The study involving four rice genotypes, i.e. three commercial varieties (Giza178, Sakha103 and Sakha106), one promising line (Gz 90576-1-3-2) as well as six bold grain lines (SKC 23819-189-1-1-1-3-1-2-4-2, SKC 23819-192-2-1-2-2-4-2-1-2, SKC 23819-192-2-1-2-3-1-1-1-2, SKC 23819192-2-1-2-4-5-3-2-1, SKC 23819-192-2-2-1-1-2-1-2-2 and SKC 23819-192$2-2-1-1-2-2-1-2)$. The parental genotypes have a wide range of variations for all studied traits. Origin and parentage of the ten parents were illustrated in Table 1. 
Table 1: Parentage of the parents utilized in this study.

\begin{tabular}{|l|c|c|c|}
\hline No. & Genotypes & Origin & Parentage \\
\hline 1 & Giza 178 & Egyptian & (Giza175/Milyang49) \\
\hline 2 & Sakha 103 & Egyptian & (Giza 177 / Suweon 349) \\
\hline 3 & Sakha 106 & Egyptian & (Giza 177 / Hexi 30) \\
\hline 4 & GZ 9057-6-1-3-2 (Giza 179) & Egyptian & (Gz 6296 / Gz 1368-S-5-4) \\
\hline 5 & SKC 23819-189-1-1-1-3-1-2-4-2 & America/ Egypt & (L 204 / Giza177) \\
\hline 6 & SKC 23819-192-2-1-2-2-4-2-1-2 & Egypt / America & (L 204 / Giza177) \\
\hline 7 & SKC 23819-192-2-1-2-3-1-1-1-2 & Egypt / America & (L 204 / Giza177) \\
\hline 8 & SKC 23819-192-2-1-2-4-5-3-2-1 & America $\square$ Egypt & (L 204 / Giza177) \\
\hline 9 & SKC 23819-192-2-2-1-1-2-1-2-2 & America $\square$ Egypt & (L 204 / Giza177) \\
\hline 10 & SKC 23819-192-2-2-1-1-2-2-1-2 & America $\square$ Egypt & (L 204 / Giza177) \\
\hline
\end{tabular}

The ten parental genotypes in this study were sown in the growing season of 2010 in three sowing dates with ( 15 days) intervals to overcome the difference of heading date among the parental varieties. After 30 days from sowing, seedling of the ten parents were transplanted to the experimental field in three rows, each row was five meters long and $(20 \times 20$ $\mathrm{cm})$ spacing between plants and rows. A line $x$ tester cross was conducted among the ten parents (four lines and six testers) in (2010) to produce (24) crosses. The hybridization technique of Jodon (1938) and modified by Butany (1961), were used and the hot water method of emasculation was utilized. The parental varieties and their resulting 24 crosses were evaluated and arranged in a randomized complete block design (RCBD) experiment with three replications in 2011 growing season. Each replication contained 34 rows and each raw contains 25 individual plant for each genotypes. The studied traits were number of days to heading (day), plant height $(\mathrm{cm})$, number of tillers plant ${ }^{-1}$, flag leaf area $\left(\mathrm{cm}^{2}\right)$, grain yield plant ${ }^{-1}(\mathrm{~g})$, number of panicle plant ${ }^{-1}$, 1000-grain weight $(\mathrm{g})$, and number of filled grains panicle 1 Genotypes means were used for the analysis of variance Singh and Chaudhary, (1985). Combining ability analysis was also performed according to Singh and Chaudhary, (1985).

The data were subjected to analysis of variances for a randomized complete block design as suggested by Panse and Sukhatme (1957) and the analysis of variance for line $x$ tester crossing followed the design of Kempthorne (1957)

\section{RESULTS AND DISSCUTION}

\section{Analysis of variance:}

Analysis of variance in Table (2) revealed that highly significant differences among the 34 genotypes (24 cross combinations, 4 lines (female parents) and 6 testers (male parents) tested for all studied characters. The parental lines and the crosses showed highly significant differences for all studied characters. Parents vs. crosses mean squares indicated that average heterosis were highly significant for all traits. On the other hand, the male testers and female lines exhibited highly significant differences for all studied characters. The highly significant mean squares of lines $\times$ testers for all 
characters indicated that they interacted and produced markedly different combining ability effects, and this might be due to the wide genetic diversity of lines and testers.

The results also illustrated that the general combining ability effect of lines (female parents) showed highly significant for all studied yield and its component characters. The general combining ability variances of testers (male parents) were highly significant for all yield and its component characters. These results were fully in agreement with EL-Refaee (2002), EL-Abd et al. (2003), EL-Mawafi and Abou Shousha (2003), Hammoud (2004), El-Rawainy et al. (2011), Asfaliza et al. (2012) and El-Namaky, (2012).

Table (2): Analysis of variance and mean square from line $x$ testers analysis for studied characters.

\begin{tabular}{|c|c|c|c|c|c|}
\hline S.O.V & D.F & \begin{tabular}{|c|}
$\begin{array}{c}\text { Days to heading } \\
\text { (days) }\end{array}$ \\
\end{tabular} & $\begin{array}{l}\text { Plant height } \\
\text { (cm) }\end{array}$ & \begin{tabular}{|c|} 
Number. of \\
tillers plant $^{-1}$
\end{tabular} & $\begin{array}{c}\text { Flag leaf area } \\
\left(\mathrm{cm}^{2}\right)\end{array}$ \\
\hline Reps. & 2 & 0.992 & 0.381 & 0.055 & 2.206 \\
\hline Genotypes & 33 & $74.09^{\star *}$ & $303.7^{\star \star}$ & $100.2^{\star *}$ & $49.59^{\star \star}$ \\
\hline Parents & 9 & $121.6^{\star *}$ & $379.37^{\star *}$ & $32.11^{\text {** }}$ & $43.92^{\star \star}$ \\
\hline P.Vs.C & 1 & $706.6^{\star \star}$ & $2839.2^{\star \star}$ & $494.2^{* *}$ & $242.29^{* *}$ \\
\hline Crosses & 23 & $28.0^{\star *}$ & $163.9^{* \star}$ & $109.8^{* *}$ & $43.43^{* *}$ \\
\hline Gca (Lines) & 3 & $106.7^{\star \star}$ & $806.4^{\star \star}$ & $721.8^{\star \star}$ & $75.59^{\star \star}$ \\
\hline Gca (Testers) & 5 & $18.11^{\star \star}$ & $60.68^{\star \star}$ & $7.917^{\star \star}$ & $47.34^{\star \star}$ \\
\hline Sca (Line $\mathrm{x}$ testers) & 15 & $15.56^{\star \star}$ & $69.93^{\star \star}$ & $21.37^{\star *}$ & $35.69^{\star \star}$ \\
\hline Error & 66 & 0.33 & 0.268 & 0.433 & 0.497 \\
\hline
\end{tabular}

*and ${ }^{\star \star}$, Significant at $5 \%$ and $1 \%$ levels of significant, respectively.

Table (2): Continue.

\begin{tabular}{|c|c|c|c|c|c|}
\hline S.O.V & D.F & $\begin{array}{l}\text { Grain yield } \\
\text { plant }^{-1} \\
\text { (g) }\end{array}$ & $\begin{array}{l}\text { Number. of } \\
\text { panicles } \\
\text { plant }^{-1}\end{array}$ & $\begin{array}{c}\text { 1000-grain } \\
\text { weight } \\
\text { (g) }\end{array}$ & $\begin{array}{c}\text { Number of } \\
\text { filled grains } \\
\text { panicle }^{-1}\end{array}$ \\
\hline Reps. & 2 & 1.569 & 0.191 & 0.003 & 26.91 \\
\hline Genotypes & 33 & $272.0^{\star *}$ & $96.02^{\star *}$ & $43.42^{\star *}$ & $2600^{\star *}$ \\
\hline Parents & 9 & $174.3^{\star \star}$ & $24.01^{* *}$ & **125.3 & **515.39 \\
\hline P.Vs.C & 1 & $2478.87^{\star *}$ & $481.6^{\star *}$ & $37.84^{* *}$ & $0.308^{* *}$ \\
\hline Crosses & 23 & $214.3^{\star *}$ & $107.4^{* *}$ & $11.59^{* *}$ & $3530^{* *}$ \\
\hline Gca (Lines) & 3 & $376.0^{\star *}$ & $721.7^{\star \star}$ & $49.97^{\star *}$ & $6216^{* *}$ \\
\hline Gca (Testers) & 5 & $234.3^{\star \star}$ & $5.840^{\star *}$ & $13.62^{\star *}$ & $4459^{\star *}$ \\
\hline Sca (Line $x$ testers) & 15 & $175.3^{\star \star}$ & $18.45^{\star \star}$ & $3.249^{\star *}$ & $2682^{\star \star}$ \\
\hline Error & 66 & 10.45 & 0.496 & 0.032 & 15.99 \\
\hline
\end{tabular}

${ }^{*}$ and $^{\star *}$, Significant at $5 \%$ and $1 \%$ levels of significant, respectively.

\section{Mean performance:}

The ordinary analysis of mean performances for all parental genotypes and their $F_{1}$ generation for studied characters are presented in Table 3 for flag leaf area and number of tillers plant ${ }^{-1}$ the highest values are preferred for breeding programs but the lowest values were desirable for number of days to heading (days), plant height $(\mathrm{cm})$. The most desirable mean values towards the earliness were obtained from parents No. $(3,2)$, Sakha 106 and Sakha 103 gave the lowest mean values (95.9 and 97.1 days), respectively. 
On the other hand, the results revealed that the crosses No. (1, 16 and 9) exhibited the lowest mean values of days to heading (106.9, 107.8 and 107.9), respectively. While, two crosses No. (23 and 21) recorded the highest mean values of days to heading (117.7 and 117.9 days), respectively.

Regarding to plant height $(\mathrm{cm})$ the shortest plant height is desirable. The two parents, No. (7 and 10) gave the lowest mean values of plant height $(68.7$ and $69.7 \mathrm{~cm})$ respect. While, Sakha 106 gave the highest mean values of $100.50 \mathrm{~cm}$. The $F_{1}$ hybrids which exhibited the highest mean values for plant height were undesirable. Three crosses, No. $(23,19$ and 21) gave the highest mean values, their mean values were $(104.4,105.3$ and $106.28 \mathrm{~cm})$, respectively. The results revealed that the crosses, No. (9, 13 and 7$)$ exhibited the lowest mean values for plant height (desirable), estimated mean values were $\left(82.1,83.9\right.$ and $84.2 \mathrm{~cm}$ ), respectively. Finally, the $F_{1}$ hybrids approximately had the highest mean values compared with their parental varieties indicated that the $F_{1}$ generation, possess the over dominance for this trait.

As for number of tillers plant ${ }^{-1}$ the parental genotypes, No. (5 and 4) recorded the highest mean values (27.3 and 27.5 tillers), respectively. While, the parental genotypes, No. (2 and 8 ) gave the lowest mean values of number of tillers (18.83 tillers). On the other hand the five crosses, No. (22, 23, 24, 19 and 21) exhibited the highest mean values it was ranged between (33.8 to 39.6 tillers). While, the three crosses, No. (6, 1 and 9) gave the lowest mean values (20.22, 20.42 and 20.71 tillers), respectively.

Concerning to flag leaf area $\left(\mathrm{cm}^{2}\right)$, the parental genotypes, No. (7) SKC 23819-192-2-1-2-3-1-1-1-2, recorded the lowest (undesirable) mean values $\left(25.83 \mathrm{~cm}^{2}\right)$, while genotypes, No. (10 and 1) scored the highest mean values (35.17 and $38.11 \mathrm{~cm}^{2}$ ), respectively. From another side, the results showed that three crosses, No. (1, 20 and 23) exhibited the highest mean values $\left(33.5,33.6\right.$ and $\left.36.8 \mathrm{~cm}^{2}\right)$, respectively. While, the two cross combinations, No. (11 and 9) gave the lowest mean values $\left(21.8\right.$ and $\left.22.38 \mathrm{~cm}^{2}\right)$, respectively.

Regarding to grain yield plant ${ }^{-1}$ the parent, No. (7) SKC 23819-192-2-12-3-1-1-1-2 and parent, No. (1) Giza178 recorded the highest mean values (62.6 and $70.3(\mathrm{~g})$ ), respectively. While, parent, No. (5) SKC 23819-189-1-11-3-1-2-4-2 and No. (6) SKC 23819-192-2-1-2-2-4-2-1-2 exhibited the lowest mean values $(44.7$ and $46.0(\mathrm{~g})$ ), respectively. On the other hand, the five crosses, No. $\left(4,15,22,24\right.$ and 18) gave the highest grain yield plant ${ }^{-1}$ their estimated mean values ranged between $(73.4$ to $81.7(\mathrm{~g}))$. While, one cross, No. (2) gave the lowest mean values for this trait their estimated value was $(41.9(\mathrm{~g}))$.

As for number of panicles plant ${ }^{-1}$, the parental genotypes, No. (4) Gz 9057-6-1-3-2 (Giza179) and No. (5) SKC 23819-189-1-1-1-3-1-2-4-2 recorded the same highest mean values (25.8 panicles plant $\left.^{-1}\right)$. While, the parental genotypes, No. (8) SKC 23819-192-2-1-2-4-5-3-2-1, No. (2) Sakha 103 and No. (10) SKC 23819-192-2-2-1-1-2-2-1-2 gave the lowest mean values $(18.3,18.5$ and 18.5 panicles plant-1), respectively. On the other hand the crosses, No. $(20,22,24,23,21$ and 19) exhibited the highest mean values their estimated mean values were ranged between (31.1 to 38.7 
panicles plant-1). While, two crosses, No. (6 and 9) gave the lowest mean values (19.4 and 19.7 panicles plant-1), respectively.

Table 3: Mean performances of parental genotypes and their $24 F_{1}$ crosses for studied characters.

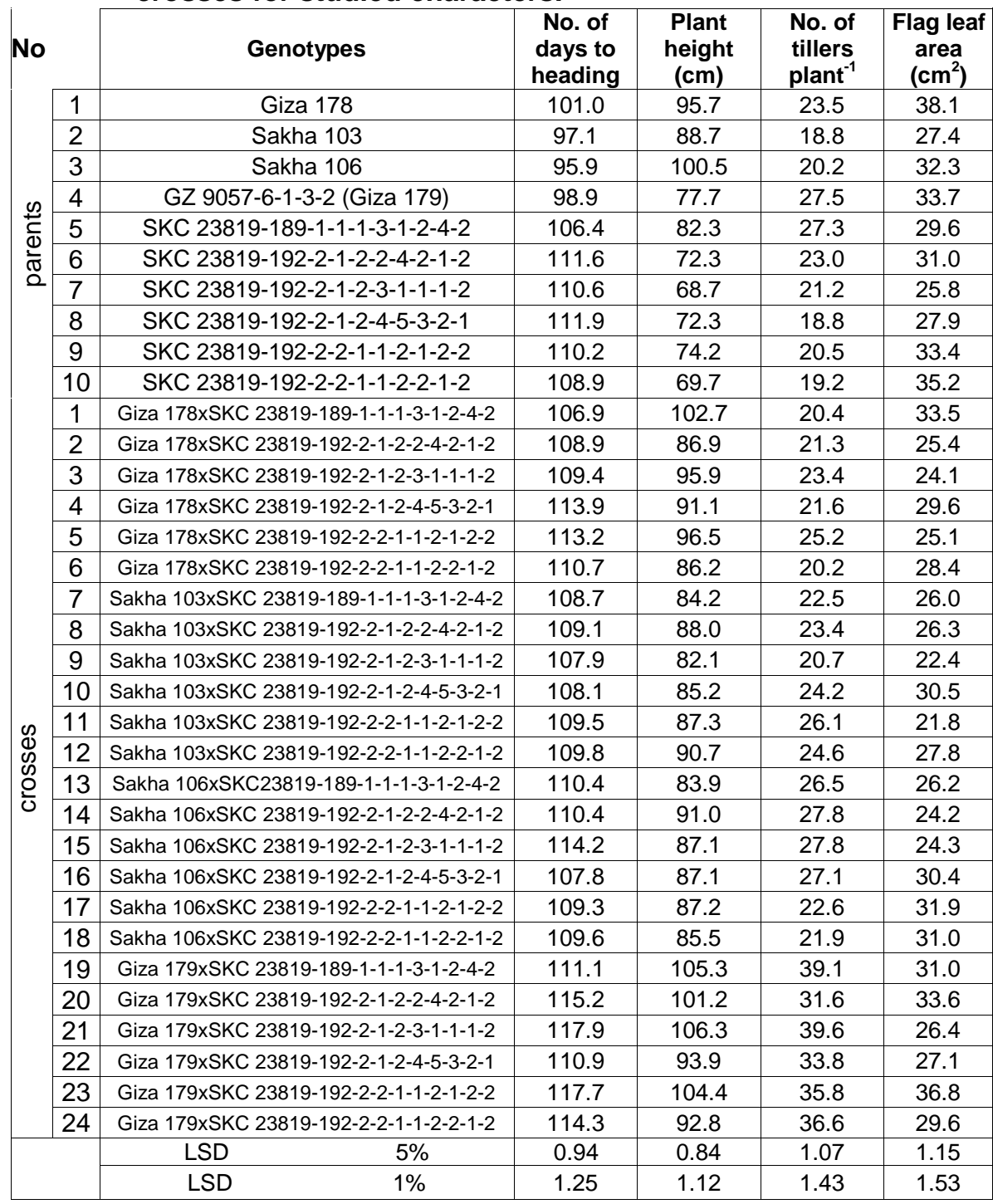

Concerning to 1000-grain weight $(\mathrm{g})$, results in table (3) showed that the parental genotypes, No. (7) SKC 23819-192-2-2-1-1-2-2-1-2 and No. (10) SKC 23819-192-2-1-2-3-1-1-1-2 exhibited the highest mean values (39.5 and 39.6 (g)) respectively, but the parental genotype, Giza 178 gave the lowest mean value $(21.7(\mathrm{~g}))$. The results revealed that the $F_{1}$ hybrids, No. $(14,24$, $11,12,18,23$ and 17) exhibited the highest mean values for 1000-grain 
weight their estimated values were ranged between $(33.4$ and 35.7 (g)), respectively. The $F_{1}$ hybrids, No. ( 3 and 4 ) gave the lowest mean values (28.7 and $29.3(\mathrm{~g})$ ), respectively.

Regarding to number of filled grains panicle ${ }^{-1}$, the parental genotype, No. (6) SKC 23819-192-2-1-2-2-4-2-1-2 recorded the lowest filled grains mean value (107.5), while the two rice genotypes, No. (40) GZ 9057-6-1-3-2 (Giza 179) and No. (1) Giza 178 recorded the highest filled grains panicle ${ }^{-1}$ mean values (134.3 and 154.5), respectively. The crosses, No. (10, 18, 19 and 21) recorded the highest filled grains panicle ${ }^{-1}$ mean values (135.2, $168.1,199.6$ and 227.9), respectively. While, the lowest filled grains panicle ${ }^{-1}$ values were found in four crosses, No. (5, 4, 6 and 23) their values (73.2, 83.9, 91.8 and 92.4), respectively.

Table 3: Continue.

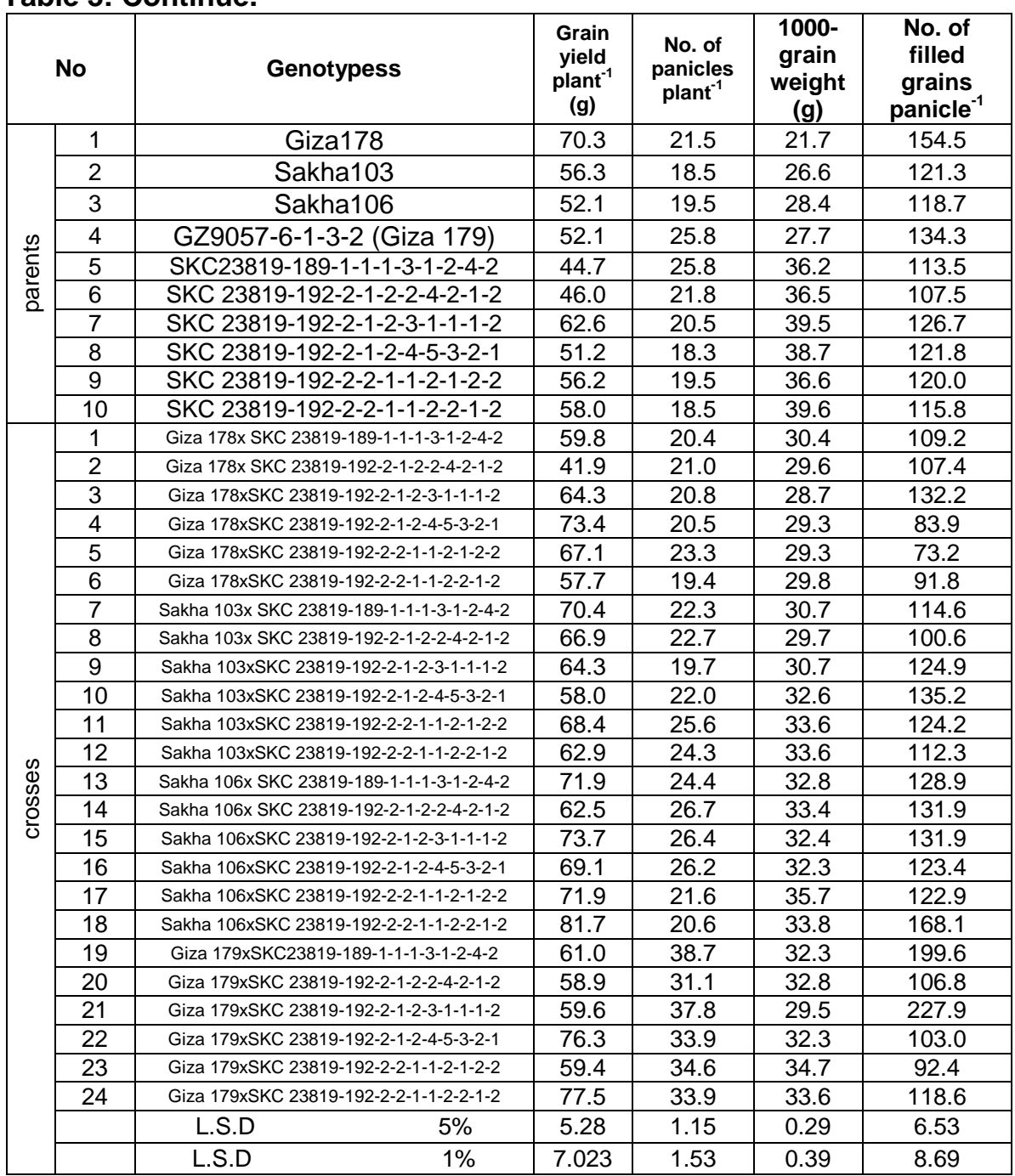




\section{Estimates of general combining ability effects (GCA):}

General combining ability effects for agronomic characters are presented in Table (4). The estimates of GCA effects for days to heading were highly significant and negative in the cases of the lines Sakha 103 (-2.175), Sakha $106(-0.771)$ and Giza $178(-0.542)$. Hence, these varieties could be considered as good combiners for early maturing. On the contrary, positive and highly significant estimate of GCA effects was detected for line GZ 9057-6-1-3-2 (3.488). In the case of the testers, No. (1) SKC 23819-1891-1-1-3-1-2-4-2 (-1.794) and No. (4) SKC 23819-192-2-1-2-4-5-3-2-1 (-0.841) were highly significant and negative. While tester, No. (5) SKC 23819-192-21-2-3-1-1-1-2 (1.311) gave high positive and significant value. Thus estimates could help in identifying the parental lines would give crosses of desirable duration. Similar results were reported by Babu and Reddy (2002), El-Keredy et al. (2003), Chakraborty et al. (2009) and Kumar et al. (2010).

With regard to plant height results in table (4), for lines, Sakha 103 and Sakha 106 were the best combiners with their GCA estimates being highly significant and negative having values $(-5.519,-4.794)$, respectively. On the contrary, other two rice varieties gave highly significant positive estimates varying from (1.431) for Giza 178 to (8.882) for GZ 9057-6-1-3-2. While in testers, No. (6 and 4) gave highly significant and negative GCA the values $(-2.965$ and -2.440$)$, respectively. On the contrary, testers, No. (3, 5 and 1$)$ gave highly significant positive GCA values (1.054, 2.086 and 2.252), respectively. The negative values of GCA effects that means decreased plant height could be useful to breed short stature rice varieties to resist the lodging and suitable for mechanical harvesting.

Concerning the number of tillers per plant, in results table (4) showed that the parental line, No. (4) Gz 9057-6-1-3-2 and testers, No. (5 and 3) were the best general combiners by virtue of their highly significant and positive estimates of GCA $(9.242,0.597$ and 1.077), respectively. On the other hand, the lines, No. (1) Giza 178, (2) Sakha 103, (3) Sakha 106 and testers, No. (6 and 2) gave highly significant and negative estimates GCA effects varying from (-4.792) for Giza 178 to (-0.802) for SKC 23819-192-2-2-1-1-2-2-1-2.

Results in table (4) revealed that the parental line, Gz 9057-6-1-3-2 and testers, No. (5, 1, 6 and 4) exhibited positive and highly significant values of GCA effects for flag leaf area, varying from (2.698) for Gz 9057-6-1-3-2 to (0.838) for SKC 23819-192-2-2-1-1-2-1-2-2. Whereas, the line Sakha 103 and testers, No. ( 3 and 2 ) gave highly significant and negative estimates of GCA effects. Their estimated values were $(-2274,-3.764$ and -0.691$)$, respectively. The results indicated that the forms four rice varieties had longer and wider leaves than the others and could be used in the rice crossing program as good combiners for increasing flag leaf area. 
Table (4): General combining ability (GCA) effects for each lines and testers for studied traits.

\begin{tabular}{|c|c|c|c|c|}
\hline Genotype & $\begin{array}{c}\text { Days to } \\
\text { heading } \\
\text { (days) }\end{array}$ & $\begin{array}{c}\text { Plant } \\
\text { height } \\
\text { (cm) }\end{array}$ & $\begin{array}{l}\text { Number. of } \\
\text { tillers plant }^{-1}\end{array}$ & $\begin{array}{c}\text { Flag leaf } \\
\text { area } \\
\left(\mathrm{cm}^{2}\right)\end{array}$ \\
\hline \multicolumn{5}{|l|}{ Line } \\
\hline $1-$ Giza 178 & $-0.542^{* *}$ & $1.431^{* *}$ & $-4.792^{\star *}$ & $-0.385^{*}$ \\
\hline 2 - Sakha 103 & $-2.175^{\star *}$ & $-5.519^{\star \star}$ & $-3.234^{\star *}$ & $-2.274^{\star *}$ \\
\hline 3-Sakha 106 & $-0.771^{\star *}$ & $-4.794^{* *}$ & $-1.216^{\star *}$ & -0.039 \\
\hline 4 - GZ 9057-6-1-3-2 (Giza 179) & $3.488^{\star \star}$ & $8.882^{\star \star}$ & $9.242^{\star \star}$ & $2.698^{\star \star}$ \\
\hline \multirow{2}{*}{$\begin{array}{lr}\text { L.S.D. } & 5 \% \\
& 1 \%\end{array}$} & 0.271 & 0.244 & 0.310 & 0.332 \\
\hline & 0.360 & 0.325 & 0.412 & 0.442 \\
\hline \multicolumn{5}{|l|}{ Tester } \\
\hline 1 - SKC 23819-189-1-1-1-3-1-2-4-2 & $-1.794^{* *}$ & $2.252^{\star *}$ & 0.295 & $1.125^{\star *}$ \\
\hline 2 - SKC 23819-192-2-1-2-2-4-2-1-2 & -0.122 & 0.012 & $-0.802^{\star \star}$ & $-0.691^{\star *}$ \\
\hline 3 - SKC 23819-192-2-1-2-3-1-1-1-2 & $1.311^{\star \star}$ & $1.054^{* *}$ & $1.077^{\star \star}$ & $-3.764^{\star \star}$ \\
\hline 4 - SKC 23819-192-2-1-2-4-5-3-2-1 & $-0.841^{* *}$ & $-2.440^{* *}$ & -0.152 & $1.327^{* *}$ \\
\hline 5 - SKC 23819-192-2-2-1-1-2-1-2-2 & $1.370^{* *}$ & $2.086^{* *}$ & $0.597^{* *}$ & $0.838^{* *}$ \\
\hline 6 - SKC 23819-192-2-2-1-1-2-2-1-2 & 0.077 & $-2.965^{\star *}$ & $-1.015^{\star *}$ & $1.165^{\star *}$ \\
\hline \multirow[t]{2}{*}{ L.S.D. } & 0.331 & 0.299 & 0.380 & 0.407 \\
\hline & 0.441 & 0.398 & 0.505 & 0.541 \\
\hline
\end{tabular}

*and $^{\star *}$, Significant at $5 \%$ and $1 \%$ levels of significant, respectively.

Results in table (4) revealed that the prenatal line, No. (3) Sakha 106 and testers No. (4 and 6) showed highly significant and positive estimates of general combining ability effects for grain yield per plant. It was highest in the case of the line Sakha 106 (6.035), and the lowest in the case of the tester, No. (4) SKC 23819-192-2-1-2-4-5-3-2-1 (3.420). These rice varieties appeared to be good parental combiners in rice crosses for increasing grain yield plant $^{-1}$. On the other hand, the tester, No. (2) SKC 23819-192-2-1-2-2-42-1-2 and line, No. (1) Giza 178 gave highly significant and negative estimates of GCA effects (-8.213 and -5.073$)$, respectively. This means that these rice varieties seemed to be poor parental combiners in rice crosses similar results were recorded by Hammoud et al (2008), Ram, et al. (2010), Mirarab et al. (2011), Parimala and Cheralu (2012) and Roy and Senapati (2012).

Results in table (4) revealed that highly significant positive GCA effects was recorded for one parental line GZ 9057-6-1-3-2 with respect to number of panicles plant $^{-1}$. The positive and highly significant GCA values were recorded for the tester, No. (1) SKC 23819-189-1-1-1-3-1-2-4-2 (0.691). In this case, these varieties could be considered as good combiner for increasing number of panicles plant ${ }^{-1}$. On the contrary, highly significant negative estimate of GCA effects were obtained for the lines Giza 178 (-4.841), Sakha 103 (-2.993), Sakha $106(-1.431)$ and the tester No. (6) $(-1.165)$

The trait of 1000-grain weight $(\mathrm{g})$ is one of the chief yield components for which genotypes with significantly positive GCA effects are needed. The lines No. (4 and 3 ) and the testers, No. (6 and 5) had highly significant and positive GCA their estimated values were $0.720,1.571,0.874$ and 1.515, respectively. These rice varieties appeared to be good parental combiners for increasing 1000-grain weight. The parental line No. (1) Giza178 and the 
testers No. (3, 2, 1 and 4) exhibited highly significant negative GCA effects for this trait. Same results were observed by Petchiammal and Kumar (2007). Rahimi, et al (2010), Selvaraj et al (2011) and Yashlok et al. (2013).

Regarding to number of filled grains panicle ${ }^{-1}$, results showed that the parental lines No. ( 3 and 4 ) and the testers No. (1 and 3 ) gave highly significant positive values of GCA effects for this trait their values were 10.97, 17.87, 14.51 and 30.72, respectively. On the contrary, highly significant negative GCA effects was recorded for lines, No. (1 and 2) and testers No. (5, 4 and 2) Giza 178, Sakha 103, SKC 23819-192-2-2-1-1-2-1-2-2, SKC 23819-192-2-1-2-4-5-3-2-1 and SKC 23819-192-2-1-2-2-4-2-1-2, their values were $-23.92,-4.916,-20.37,-12.15$ and -11.88 respectively. These genotypes could be considered as poor combiners for filled grains panicle ${ }^{-1}$, same findings were detected by Punitha et al. (2004), Gnanasekaran, et al. (2006) and Selvaraj et al. (2011).

Table (4): Continue.

\begin{tabular}{|c|c|c|c|c|}
\hline Genotype & $\begin{array}{l}\text { Grain yield } \\
\text { plant }^{-1}(\mathrm{~g})\end{array}$ & $\begin{array}{c}\text { Number.of } \\
\text { panicles plant }\end{array}$ & $\begin{array}{l}\text { 1000-grain } \\
\text { weight(g) }\end{array}$ & $\begin{array}{l}\text { Number .of filled } \\
\text { grains panicle }^{1}\end{array}$ \\
\hline \multicolumn{5}{|l|}{ Lines } \\
\hline 1-Giza 178 & $-5.073^{\star *}$ & $-4.841^{\star \star}$ & $-2.311^{\star \star}$ & $-23.92^{\star \star}$ \\
\hline 2-Sakha 103 & -0.639 & $-2.993^{\star *}$ & 0.019 & $-4.916^{\star *}$ \\
\hline 3-Sakha 106 & $6.035^{\star \star}$ & $-1.431^{\star *}$ & $1.571^{\star \star}$ & $10.97^{\star \star}$ \\
\hline 4-GZ 9057-6-1-3-2 (Giza 179) & -0.323 & $9.265^{\star \star}$ & $0.720^{\star \star}$ & $17.87^{\star \star}$ \\
\hline \multirow{2}{*}{$\begin{array}{ll}\text { L.S.D. } & 5 \% \\
& 1 \%\end{array}$} & 1.524 & 0.332 & 0.084 & 1.885 \\
\hline & 2.027 & 0.442 & 0.112 & 2.507 \\
\hline \multicolumn{5}{|l|}{ Testers } \\
\hline 1-SKC 23819-189-1-1-1-3-1-2-4-2 & 0.019 & $0.691^{\star \star}$ & $-0.235^{\star \star}$ & $14.51^{\star \star}$ \\
\hline 2-SKC 23819-192-2-1-2-2-4-2-1-2 & $-8.213^{\star \star}$ & -0.372 & $-0.448^{\star \star}$ & $-11.88^{\star \star}$ \\
\hline 3-SKC 23819-192-2-1-2-3-1-1-1-2 & -0.336 & $0.410^{*}$ & $-1.526^{\star *}$ & $30.72^{* *}$ \\
\hline 4-SKC 23819-192-2-1-2-4-5-3-2-1 & $3.420^{* *}$ & -0.097 & $-0.181^{* *}$ & $-12.15^{\star *}$ \\
\hline 5-SKC 23819-192-2-2-1-1-2-1-2-2 & 0.924 & $0.532^{*}$ & $1.515^{\star *}$ & $-20.37^{* *}$ \\
\hline 6-SKC 23819-192-2-2-1-1-2-2-1-2 & $4.186^{\star \star}$ & $-1.165^{\star \star}$ & $0.874^{\star *}$ & -0.836 \\
\hline \multirow[t]{2}{*}{ L.S.D. } & 1.867 & 0.407 & 0.103 & 2.309 \\
\hline & 2.483 & 0.541 & 0.137 & 3.071 \\
\hline
\end{tabular}

*and ${ }^{\star \star}$, Significant at $5 \%$ and $1 \%$ levels of significant, respectively.

\section{Estimates of specific combining ability effects (SCA):}

The specific combining ability effects as shown in (Table 5 ) revealed that out of 24 crosses, ten cross combinations, No. $(1,2,3,9,11,16,17,18$, 19 and 22) exhibited significant or highly significant negative specific combining ability effects for days to heading, indicating that these crosses were the best combinations for earliness. The values ranged from -2.714 for cross, No. (22) to- 0.701 for cross, No. (11). While, nine crosses, No. (4, 5, 7, $12,13,15,20,21$ and 23) gave significant and highly significant positive specific combining ability indicating that these cross combinations were undesirable types. This results in good agreement with those found by ElRefaee (2002), Hammoud (2004), Singh and Kumar (2005), Sedeek (2006) and Ganapathy et al. (2007). In such case where additive gene effects was played a predominant role in association with numbern-additive component, the recurrent selection or reciprocal recurrent selection, were important to improve trait. 
In case of plant height, significant negative or positive SCA effects was recorded in 22 crosses for plant height. Ten combinations showed highly significant negative values of SCA effects for plant height. The crosses, No. $(2,6,7,9,11,13,15,17,22$ and 24) their estimated SCA values were, ranged between -6.334 for cross, No. (2) and -0.950 for cross, No. (15). The hybrids showed significant negative SCA effects may be useful in exploitation of heterosis due to their desirable stature. The highly significant positive ranged from 1.198 for cross, no. 5 to 7.411 for cross, No. (12).

Results in table (5) showed that number of tillers plant ${ }^{-1}$, were significant and highly significant positive SCA effects for in ten cross combinations, No. $(5,10,11,12,14,15,16,19,21$ and 24) their values were ranged from 0.738 in cross, No. (10) to 3.014 in cross combination, No. (14). Significant and highly significant negative were recorded in nine crosses which ranged from -3.963 in cross, No. (9) to-0.802 in cross, No. (6). The negative SCA effects for tillers number indicated presence of undesirable non-additive interactions.

Table (5): Estimates of specific combining ability (SCA) effects for studied characters.

\begin{tabular}{|c|c|c|c|c|c|}
\hline No & Hybrid & $\begin{array}{c}\text { No. of days } \\
\text { to heading } \\
\text { (days) }\end{array}$ & $\begin{array}{c}\text { Plant } \\
\text { height }(\mathbf{c m})\end{array}$ & $\begin{array}{l}\text { No. of } \\
\text { tillers } \\
\text { plant }^{-1}\end{array}$ & $\begin{array}{c}\text { Flag leaf } \\
\text { area } \\
\left(\mathrm{cm}^{2}\right) \\
\end{array}$ \\
\hline 1 & Giza 178x SKC 23819-189-1-1-1-3-1-2-4-2 & $-1.84^{\star \star}$ & $7.25^{\star *}$ & $-1.91^{\star *}$ & $4.69^{* *}$ \\
\hline 2 & Giza 178x SKC 23819-192-2-1-2-2-4-2-1-2 & $-1.43^{* *}$ & $-6.33^{* *}$ & 0.05 & $-1.62^{\star *}$ \\
\hline 3 & Giza 178xSKC 23819-192-2-1-2-3-1-1-1-2 & $-2.42^{\star \star}$ & $1.62^{* *}$ & 0.33 & 0.22 \\
\hline 4 & Giza 178xSKC 23819-192-2-1-2-4-5-3-2-1 & $4.25^{\star *}$ & 0.34 & -0.27 & 0.57 \\
\hline 5 & Giza 178xSKC 23819-192-2-2-1-1-2-1-2-2 & $1.32^{* *}$ & $1.19^{\star *}$ & $2.60^{* *}$ & $-3.45^{\star *}$ \\
\hline 6 & Giza 178xSKC 23819-192-2-2-1-1-2-2-1-2 & 0.13 & $-4.07^{\star \star}$ & $-0.80^{*}$ & -0.42 \\
\hline 7 & Sakha 103x SKC 23819-189-1-1-1-3-1-2-4-2 & $1.61^{* *}$ & $-4.33^{\star \star}$ & $-1.38^{\star *}$ & $-0.89^{*}$ \\
\hline 8 & Sakha 103x SKC 23819-192-2-1-2-2-4-2-1-2 & 0.39 & $1.77^{* \star}$ & 0.65 & $1.16^{\star *}$ \\
\hline 9 & Sakha 103xSKC 23819-192-2-1-2-3-1-1-1-2 & $-2.27^{* \star}$ & $-5.24^{\star *}$ & $-3.96^{\star *}$ & 0.35 \\
\hline 10 & Sakha 103xSKC 23819-192-2-1-2-4-5-3-2-1 & 0.07 & $1.42^{* \star}$ & $0.74^{*}$ & $3.35^{\star *}$ \\
\hline 11 & Sakha 103xSKC 23819-192-2-2-1-1-2-1-2-2 & $-0.70^{*}$ & $-1.03^{\star *}$ & $1.94^{\star *}$ & $-4.86^{\star *}$ \\
\hline 12 & Sakha 103xSKC 23819-192-2-2-1-1-2-2-1-2 & $0.89^{\star \star}$ & $7.41^{* *}$ & $2.00^{* *}$ & $0.88^{*}$ \\
\hline 13 & Sakha 106xSKC 23819-189-1-1-1-3-1-2-4-2 & $1.91^{* *}$ & $-5.28^{\star *}$ & 0.55 & $-2.94^{\star *}$ \\
\hline 14 & Sakha 106xSKC 23819-192-2-1-2-2-4-2-1-2 & 0.21 & $4.04^{\star \star}$ & $3.01^{\star *}$ & $-3.08^{\star \star}$ \\
\hline 15 & Sakha 106xSKC 23819-192-2-1-2-3-1-1-1-2 & $2.58^{* *}$ & $-0.95^{* *}$ & $1.16^{\star *}$ & 0.06 \\
\hline 16 & Sakha 106xSKC 23819-192-2-1-2-4-5-3-2-1 & $-1.61^{\star *}$ & $2.54^{\star \star}$ & $1.65^{\star \star}$ & $1.07^{*}$ \\
\hline 17 & Sakha 106xSKC 23819-192-2-2-1-1-2-1-2-2 & $-2.36^{\star *}$ & $-1.86^{\star \star}$ & $-3.66^{\star *}$ & $3.06^{\star \star}$ \\
\hline 18 & Sakha 106xSKC 23819-192-2-2-1-1-2-2-1-2 & $-0.73^{*}$ & $1.50^{\star *}$ & $-2.72^{\star *}$ & $1.83^{\star *}$ \\
\hline 19 & Giza 179xSKC 23819-189-1-1-1-3-1-2-4-2 & $-1.68^{\star \star}$ & $2.37^{\star \star}$ & $2.74^{\star \star}$ & $-0.86^{\star}$ \\
\hline 20 & Giza 179xSKC 23819-192-2-1-2-2-4-2-1-2 & $0.83^{*}$ & 0.52 & $-3.72^{\star \star}$ & $3.54^{* *}$ \\
\hline 21 & Giza 179xSKC 23819-192-2-1-2-3-1-1-1-2 & $2.11^{* *}$ & $4.57^{* \star}$ & $2.47^{* *}$ & -0.64 \\
\hline 22 & Giza 179xSKC 23819-192-2-1-2-4-5-3-2-1 & $-2.71^{\star *}$ & $-4.30^{\star *}$ & $-2.12^{\star *}$ & $-4.99^{\star \star}$ \\
\hline 23 & Giza 179xSKC 23819-192-2-2-1-1-2-1-2-2 & $1.75^{\star \star}$ & $1.69^{\star \star}$ & $-0.89^{*}$ & $5.25^{\star \star}$ \\
\hline \multirow[t]{3}{*}{24} & Giza 179xSKC 23819-192-2-2-1-1-2-2-1-2 & -0.29 & $-4.85^{\star *}$ & $1.52^{* *}$ & $-2.30^{* *}$ \\
\hline & L.S.D. & 0.663 & 0.598 & 0.760 & 0.814 \\
\hline & L.S.D & 0.881 & 0.796 & 1.010 & 1.083 \\
\hline
\end{tabular}

${ }^{*}$ and $^{\star \star}$, Significant at $5 \%$ and $1 \%$ levels of significant, respectively.

With regarding to flag leaf area in table (5), it is obvious that 18 crosses had significant or highly significant positive and negative values of SCA effects. The crosses, No. $(1,8,10,12,16,17,18,20$ and 23), exhibited the 
highest positive SCA effects with respective values of $(4.693,1.160,3.349$, $0.885,1.068,3.057,1.835,3.543$ and 5.251 ). On the contrary, nine crosses showed significant or highly significant negative estimates of SCA effects for this character. The highest value was -4.989 and the lowest value was -0.862 for the crosses, No. (22 and 19), respectively. The combinations showed high positive estimates can be utilized for improvement flag leaf area.

As for grain yield plant ${ }^{-1}$, estimates of SCA effects from the $24 F_{1}$ crosses are shown in table (5). It is obvious that eight crosses gave significant and highly significant positive estimates of SCA effects. The highest values were (9.966) in cross, No. (8), followed by (9.245) in cross, No. (4), (7.889) in cross, No. (24) and (7.401) in cross, No. (22). In spite of the cross combinations, No. (2, 6, 10, 12, 16, 19, 21 and 23), gave significant and highly significant negative estimates of SCA effects. Their values ranged from -10.58 for cross, No. (2) to- 4.439 for cross, No. (19). These results in good according with those reported by Hammoud et al. (2008) and Kelah (2012)

As for panicles number plant $^{-1}$, eight combinations recorded highly significant positive values of SCA effects their values were 1.868 in cross, No. (5), 2.286 for cross No. (11), 2.728 for cross, No. (12), 2.767 for cross, No. (14), 1.663 for cross, No. (15), 1.959 for cross, No. (16), 2.997 for cross, No. (19) and 2.328 for cross, No. (21). On the contrary, eight crosses showed significant or highly significant negative SCA effects for this trait and gave values ranged between -3.529 for cross, No. (20) and -0.922 for cross combinations, No. (23).

With regarding to 1000-grain weight $(\mathrm{g})$. (12) hybrid combinations recorded highly significant positive SCA effects, for hybrid, No. (1) the maximum SCA value was 1.138 , Other important hybrids combinations were, No. $(2,3,9,10,11,12,14,15,17,20$ and 23) which exhibited positive SCA effects their estimated value were ranged between 0.289 for cross, No. (11) and 0.967 for cross, No. (10). Also, eight hybrids gave highly significant negative SCA effects these crosses were, No. $(5,6,7,8,13,16$, 18 and 21) their values were $-1.674,-0.620,-0.855,-1.677,-0.319$, $-0.903,-0.503$ and -1.527 , respectively. These results are similar with that found by Sharma and Mani (2001) and Sanjeev et al. (2006), El-Rawainy et al. (2011), El-Badri (2013) and Anees (2013). They identified various good combiners for the improvement of 1000-grain weight in rice.

Concerning filled grains panicle ${ }^{-1}$ in table (5), it is obvious that eight crosses had highly significant positive values of SCA effects. The crosses, No. $(2,10,11,14,17,18,19$ and 21) exhibited the highest SCA effects with respective values of $19.63,28.71,25.92,9.258,8.769,34.40,43.64$ and 55.87. On the other hand, 13 crosses showed significantly negative estimates of SCA effects for this trait. Their values were ranged between -33.35 for cross No. (15) and -4.954 for cross No. (1). 
Table (5): Estimates of specific combining ability (SCA) effects for studied characters.

\begin{tabular}{|c|c|c|c|c|c|}
\hline NO & Hybrid & $\begin{array}{c}\text { Grain } \\
\text { yield } \\
\text { plant }^{-1}(\mathrm{~g})\end{array}$ & $\begin{array}{c}\text { No. of } \\
\text { panicles }^{-1} \\
\text { plant }^{-1}\end{array}$ & $\begin{array}{l}\text { 1000-grain } \\
\text { weight (g) }\end{array}$ & $\begin{array}{l}\text { No. of filled } \\
\text { grains } \\
\text { panicle }^{-1}\end{array}$ \\
\hline 1 & Giza 178xSKC 23819-189-1-1-1-3-1-2-4-2 & -0.88 & $-1.18^{\star *}$ & $1.14^{\star *}$ & $-4.95^{\star}$ \\
\hline 2 & Giza 178x SKC 23819-192-2-1-2-2-4-2-1-2 & $-10.58^{\star *}$ & 0.48 & $0.525^{\star *}$ & $19.63^{\star *}$ \\
\hline 3 & Giza 178xSKC 23819-192-2-1-2-3-1-1-1-2 & $3.93^{*}$ & -0.55 & $0.679^{\star *}$ & 1.89 \\
\hline 4 & Giza 178xSKC 23819-192-2-1-2-4-5-3-2-1 & $9.24^{\star \star}$ & -0.31 & -0.048 & -3.55 \\
\hline 5 & Giza 178xSKC 23819-192-2-2-1-1-2-1-2-2 & $5.47^{\star \star}$ & $1.87^{\star *}$ & $-1.674^{\star *}$ & $-6.05^{\star}$ \\
\hline 6 & Giza 178xSKC 23819-192-2-2-1-1-2-2-1-2 & $-7.19^{\star \star}$ & -0.31 & $-0.620^{\star *}$ & $-6.98^{\star \star}$ \\
\hline 7 & Sakha 103xSKC 23819-189-1-1-1-3-1-2-4-2 & $5.24^{\star *}$ & $-1.19^{\star \star}$ & $-0.855^{\star \star}$ & $-18.55^{\star *}$ \\
\hline 8 & Sakha 103xSKC 23819-192-2-1-2-2-4-2-1-2 & $9.97^{\star \star}$ & 0.28 & $-1.677^{\star *}$ & $-6.19^{\star \star}$ \\
\hline 9 & Sakha 103xSKC 23819-192-2-1-2-3-1-1-1-2 & -0.55 & $-3.44^{\star *}$ & $0.341^{* *}$ & $-24.41^{* *}$ \\
\hline 10 & Sakha 103xSKC 23819-192-2-1-2-4-5-3-2-1 & $-10.56^{\star *}$ & -0.66 & $0.967^{\star *}$ & $28.71^{\star *}$ \\
\hline 11 & Sakha 103xSKC 23819-192-2-2-1-1-2-1-2-2 & 2.39 & $2.29^{\star \star}$ & $0.289^{\star \star}$ & $25.92^{\star \star}$ \\
\hline 12 & Sakha 103xSKC 23819-192-2-2-1-1-2-2-1-2 & $-6.42^{\star \star}$ & $2.73^{\star *}$ & $0.935^{\star \star}$ & $-5.48^{*}$ \\
\hline 13 & Sakha 106xSKC23819-189-1-1-1-3-1-2-4-2 & 0.08 & -0.62 & $-0.319^{\star *}$ & $-20.13^{\star *}$ \\
\hline 14 & Sakha 106xSKC 23819-192-2-1-2-2-4-2-1-2 & -1.09 & $2.77^{\star \star}$ & $0.442^{\star *}$ & $9.26^{\star \star}$ \\
\hline 15 & Sakha 106xSKC 23819-192-2-1-2-3-1-1-1-2 & 2.18 & $1.66^{\star \star}$ & $0.506^{\star *}$ & $-33.35^{\star *}$ \\
\hline 16 & Sakha 106xSKC 23819-192-2-1-2-4-5-3-2-1 & $-6.08^{\star \star}$ & $1.96^{\star \star}$ & $-0.903^{* *}$ & 1.06 \\
\hline 17 & Sakha 106xSKC 23819-192-2-2-1-1-2-1-2-2 & -0.79 & $-3.23^{\star *}$ & $0.777^{\star *}$ & $8.77^{* *}$ \\
\hline 18 & Sakha 106xSKC 23819-192-2-2-1-1-2-2-1-2 & $5.72^{\star \star}$ & $-2.53^{\star \star}$ & $-0.503^{\star \star}$ & $34.40^{\star *}$ \\
\hline 19 & Giza 179xSKC 23819-189-1-1-1-3-1-2-4-2 & $-4.44^{*}$ & $2.99^{* *}$ & 0.036 & $43.64^{\star \star}$ \\
\hline 20 & Giza 179xSKC 23819-192-2-1-2-2-4-2-1-2 & 1.71 & $-3.53^{\star \star}$ & $0.710^{\star *}$ & $-22.70^{\star *}$ \\
\hline 21 & Giza 179xSKC 23819-192-2-1-2-3-1-1-1-2 & $-5.56^{\star \star}$ & $2.33^{\star *}$ & $-1.527^{\star \star}$ & $55.87^{\star \star}$ \\
\hline 22 & Giza 179xSKC 23819-192-2-1-2-4-5-3-2-1 & $7.40^{\star \star}$ & $-0.99^{*}$ & -0.016 & $-26.22^{\star *}$ \\
\hline 23 & Giza 179xSKC 23819-192-2-2-1-1-2-1-2-2 & $-7.00^{\star *}$ & $-0.92^{*}$ & $0.608^{\star *}$ & $-28.64^{* *}$ \\
\hline 24 & Giza 179xSKC 23819-192-2-2-1-1-2-2-1-2 & $7.89^{\star \star}$ & 0.11 & 0.188 & $-21.94^{* *}$ \\
\hline & L.S.D & 3.734 & 0.813 & 0.207 & 4.618 \\
\hline & L.S.D & 4.966 & 1.082 & 0.275 & 6.142 \\
\hline
\end{tabular}

*and ${ }^{\star \star}$, Significant at $5 \%$ and $1 \%$ levels of significant, respectively.

\section{REFERENCES}

Anees, G. B. (2013). Development and Evaluation of New Restorer and Maintainer Lines and Their Relationship to Heterosis in Rice. PhD. thesis Agric., Sci. (Genetics). Mansura Univ.

Asfaliza, R.; M. Y. Rafii; G. Saleh; O. Omar and A. Puteh (2012). Combining ability and heritability of selected rice varieties for grain quality traits. Austr. J. of Crop Sci.; 6 (12): 1718-1723.

Babu, S. S and P. S. Reddy (2002). Combining ability analysis in rice (Oryza sativa, L.). Res. on Crops. 3 (3): 592-598.

Bansal, U. K.; R. G. Saini and N. S. Rani (2000). Heterosis and combining ability for yield its components and quality traits in some scented rice (Oryza sativa L.). Tropical Agric., 77: 180-187.

Butany, W. T. (1961). Mass emasculation in rice. Inter. Rice Com. Newsletter, 9: $9-13$

Chakraborty, R.; S. Chakraborty; B. K. Dutta and S. B. Paul (2009). Combining ability analysis for yield and yield components in bold grained rice (Oryza sativa L.) of Assam. Acta. Agron. (Palmira) 58 (1): 9-13. 
El-Abd, A. B.; A. A. Abdallah and A. A. El-Hissewy (2003). Studies on combining ability and heterosis for some physiological characters in rice (Oryza sativa L.). The Tenth Conference of Agron. October, 7-10. Suez Canal Univ. El-Irish, Egypt.

El-Badri, A. M. A. (2013). Genetical studies on some rice varieties for resistant to blast disease. M. Sc.thesis Genetics, Fac. of Agric, Mansoura Univ., mansoura Egypt.

El-Keredy, M. S.; A. E. Draz; A. Y. Ragab; A. A. Abdallah and A. A. ElMouhamady (2003). Combining ability for some quantitative characters in rice (Oryza sativa L.). Under normal and saline soil conditions. The tenth conf. of agro. October, 7-10. Suez Canal Univ. El-Irish, Egypt.

El-Mowafi, H. F. and A. A. Abou Shousha (2003). Combining ability and heterosis analysis of diverse CMS lines in hybrid rice. J. Agric. Res., Tanta Univ., 29 (1): 106-127.

El-Namaky, R. A. J. (2012). Heterosis and combining ability of some agronomic and physiological characters in rice.J. Agric. Res., Kafr ElSheikh Univ., 38 (2): 266-283.

El-Rawainy, I. M. O.; H. M. Hassan and A. B. El-Abd (2011). A study on heterosis and combining ability for grain yield and its component traits in rice under water stress conditions. J. Agric. Res. Kafr El-Sheikh Univ., 37 (4): 583-598.

El-Refaee, Y. Z. E. (2002). Genetical and biochemical studies on heterosis and combining ability in rice. M.Sc. Thesis, Fac. of Agric., Tanta Univ., Kafr El-Sheikh, Egypt.

Ganapathy, S.; S. K. Ganesh; P. Vivekanandan; P. Shanmugasundaram and R. C. Babu (2007).Variability and interrelationship between yield and physio-morphological traits in rice (Oryza sativa L.) under moisture stress condition. Crop Res. Hisar., 34 (3): 260-262.

Gnanasekaran, M.; P. Vivekanandan and S. Muthuramu (2006). Combining ability and heterosis for yield and grain quality in two line rice (Oryza sativa L.) hybrids. Ind. J. Genet., 66 (1): 6-9.

Hammoud, S. A. A.; I. S. M. El-Degwy; S. E. M. Sedeek and B. A. Zayed (2008). Line $x$ Tester analysis for some quantitative traits in rice. Proceedings of The Second Field Crops Conference, FCRI, ARC, Giza, Egypt, 14-16 Oct.: 121-140.

Hammoud, S. A. M. (2004). Inheritance of some quantitative characters in rice (Oryza sativa L.). Ph. D. Thesis, Fac. Agric. Minofiya Univ., Shibin El-Kom, Egypt.

Jodon, N. E. (1938). Experiments on artificial hybridization of rice. J. Mer. Soc. Agron., 30 (4):249-305.

Kelah, M. I. M. (2012). Genetic studies on earliness yield and its components for some rice genotypes. M.Sc. Thesis, Fac. Agric., Kafr El-Sheikh Univ. Egypt.

Kempthorne, O. (1957). An Introduction to Genetic Statistics. John Wiley and Sons Inc., New York. 
Khush, G. S. (1999). Redesigning rice photosynthesis to increase yield. Proceeding of the Workshop on the Quest to Reduce Hunger: Redesigning rice photosynthesis, 30 Nov - 3 Dec. Los Banos, Philippines.

Kumar, P. S.; K. Saravanan and T. Sabesan (2010). Combining ability for yield and yield contributing characters in rice (Oryza sativa L.). Electronic J. of Plant Breed. 1 (5):1290-1293.

Mirarab, M.; A. Ahmadikhah and M. H. Pahlavani (2011). Study on combining ability, heterosis and genetic parameters of yield traits in rice. African Journal of Biotechnology; 10 (59):12512-12519.

Panse, V. G. and P. V. Sukhatme (1957). Statistical Methods for Agricultural Workers. Indian Council of Agric. Res. New Delhi, India.

Parimala, K. and C. Cheralu (2012). Combining ability studies in indica and japonica genotypes of rice. Crop Improvement, 39 (1):127-129.

Petchiammal, K. I. and C. R. A. Kumar (2007). Combining ability studies for yield and yield associated traits in rice (Oryza sativa L.) involving Assam rice cultivars. Inter. J. Agric. Sci., 3 (2): 234-236.

Punitha, D.; A. J. Joel; S. Manumbermani and K. Thiyagarajan (2004). Combining ability for yield and its components. Advances in Plant Sci., 17 (1): 345-348.

Rahimi, M.; B. Rabiei; H. Samizadeh and A. K. Ghasemi (2010). Combining ability and heterosis in rice (Oryza sativa L.). Cultivars. J. Agric. Sci. Tech, 12: 223-231.

Ram, M.; G. P. Verma; M. Kumar and O. N. Singh (2010). Combining ability analysis for grain yield and its components in short duration rice (Oryza sativa L.). Plant Archives; 10 (1):361-365.

Roy, S. K. and B. K. Senapati (2012). Combining ability analysis for grain yield and quality characters in rice (Oryza sativa). Ind. J. of Agric. Sci., 82 (4):293-303.

Sanjeev, K.; H. B. Singh; J. K. Sharma and S. Sood (2006). Combining ability and gene action for grain yield and associated traits in segregating generation of rice (Oryza sativa). Ind. J. of Agri. Sci., 76 (9):566-569.

Sedeek, S. E. M. (2006). Breeding studies on rice. Ph.D. Thesis, Faculty of Agric., Kafr El-Sheikh, Tanta Univ., Egypt.

Selvaraj, C. I.; P. Nagarajan; K. Thiyagarajan; M. Bharathi and R. Rabindran (2011). Studies on heterosis and combining ability of well-known blast resistant rice genotypes with high yielding varieties of rice (Oryza sativa L.). Inter. J. plant breed and genet, 5 (2): 111-129.

Sharma, R. K. and S. C. Mani (2001). Combining ability studies for grain yield and other associated characters in basmati rice (Oryza sativa L.). Crop improvement, 28 (2): 236-243.

Singh, N. K. and A. Kumar (2005). Combining ability analysis to identify suitable parents for heterotic rice hybrid breeding. Inter. Rice Res. Newsletter, 29 (1): 21-22.

Singh, A.K. and B .D. Chaudhary. (1985). Biometrical Methods in Quantitative Genetic Analysis. Kalyani Publisher, New Dehli, India. 
Yashlok, S.; P.B. Patel; P.K. Singh and S. Vinumberd. (2013). Combining ability analysis for salt tolerance in rice (Oryza sativa L.) under costal salt affected soil. Trends in Biosciences. 6 (6): 776-780

تقلير القدرة على الايتلاف لبعض الصفات الخضرية والمحصولية لبعض التراكيب

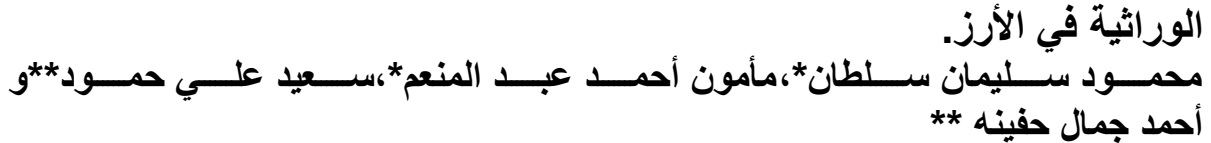
* قسم المحاصيل كلية الزراعة - جامعة المئه المنصورة

** قسم البحوث والتدريب فى الأرز سخا ـ معهد المحاصيل الحقلية ـ مركز البحوث الزراعية

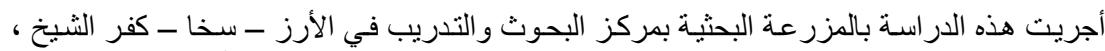

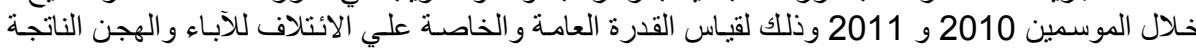

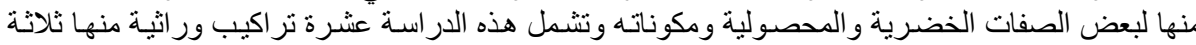

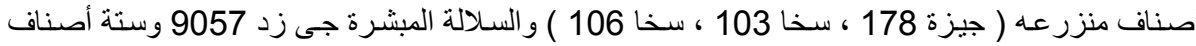

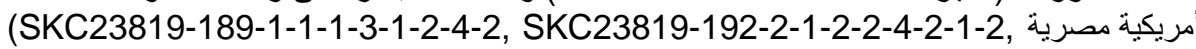
SKC23819-192-2-1-2-3-1-1-1-2, SKC23819-192-2-1-2-4-5-3-2-1, SKC23819ون 192-2-2-1-1-2-1-2-2 and SKC23819-192-2-2-1-1-2-2-1-2 وتمتاز هذه الآبـاء بمدى الأب

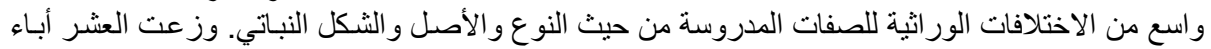

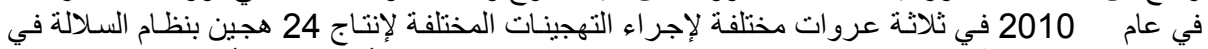

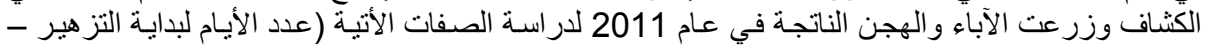

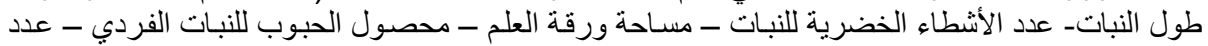

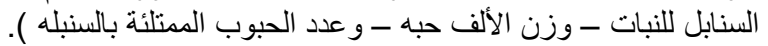

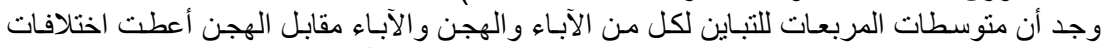

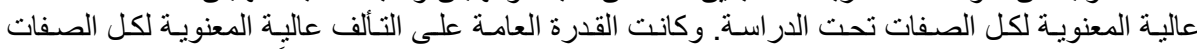

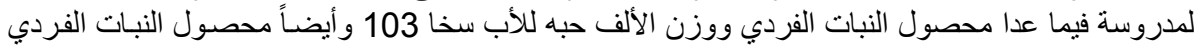

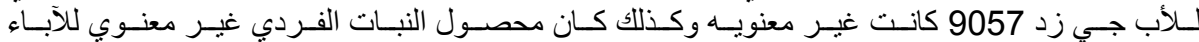
SKC23819-189-1-1-1-3-1-2-4-2, SKC 23819-192-2-1-2-3-1-1-1-2, SKC

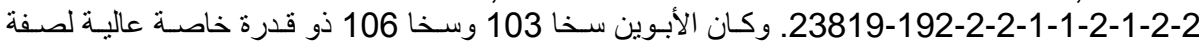

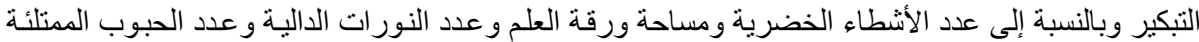

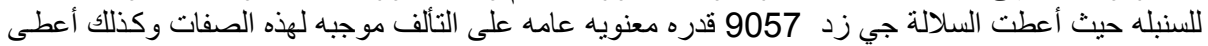

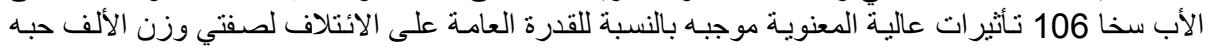

وبالنسبة للسـلالات تعتبر السلالة 23819-192-2-2-1-1-2-1-2-2

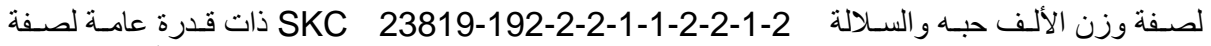
محصول الحبوب للنبات الفردي وتعتبر هذه الصفة من الصفات المهمة في برامج التربية لإنتاج أصناف عالية

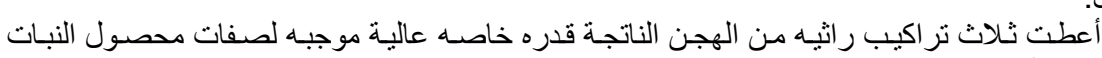
المحصول.

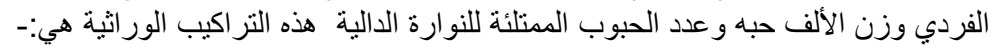
Sakha 103xSKC 23819-192-2-1-2-2-4-2-1-2, Giza 178xSKC 23819189-1-1-1-3-1-2-4-2 and Giza 179xSKC 23819-192-2-1-2-3-1-1-1-2 